Spermatogonia, spermatocytes of the I and II order and spermatids were observed in the majority of the sperm ducts of the testis. Only a few ducts (mostly circumferential) contained spermatozoa also (Photo. 2). Numerous active Leydig's cells can be seen in the interstitial tissue. The epithelium of the head of the epididymis exhibited intensive secretory activity. The prostate (Photo. 3) and glandular epithelium of gl. ampullarum exhibited intensive secretory activity, as did the epithelium of the vesicles of $\mathrm{gl}$. bulbo-urethrales.

The first, and up to the present the only, mention made of sexual maturation of young males of $S$. araneus in the first calendar year of life was made by B a u e r (1960). This author caught two sexually active young males on September 4th and November 8th in the Neusiedlersee district in Austria. Their weight was respectively 11.5 and $11.6 \mathrm{~g}$, the testes measured $8 \times 5 \mathrm{~mm}$. Weaker progression of the gonads in young males was observed by P u c e k (1960), but in these cases no spermatozoa were found in the testicles.

The individual described above was in process of sexual maturation. Probably, if it had been caught a month later, it would have been a fully sexually active male. The low body weight $(6.0 \mathrm{~g})$ of this individual, characteristic of young sexually immature shrews, would seem to indicate that the sexual maturation of young animals is not necessarily accompanied by a jump in weight (cf. P u c e k, 1960).

\title{
REFERENCES
}

B a u e r K., 1960: Die Säugetiere des Neusiedlersee-Gebietes. Bonn. zool. Beitr., 11, 2-4: 141-352. Pucek Z., 1960: Sexual maturation and variability of the reproductive system in young Shrews (Sorex L.) in the first calendar year of life. Acta theriol., 3: 269-296.

Department of Comparative Anatomy, Wroclaw University, Wrocław, Sienkiewicza 21. Received, December 2, 1966.

\section{Włodzimierz JEZIERSKI}

\section{FOUR CASES OF »HOME INSTINCT» IN THE EUROPEAN HARE \\ CZTERY PRZYPADKI "INSTYNKTU DOMU}

There were described four cases of returning European hares to their place of origin from the distance of 230 and $460 \mathrm{~km}$.

Some species of animals have the ability to find certain places and especially the places in which they were recently settled. The return to the place of origin was first described in Peromyscus maniculatus by J ohnson (1926). The same species was later studied by Murie \& M u rie (1931). They named this phenomenon "home instinct" and defined it as the tendency of some animal species to return to the habitat they were previously forced to leave. Subsequently »home instinct « was described by numerous investigators (F en juk, 1941; F en juk \& P op ova, 1940; Schmid, 1936; T own send, 1935 and others).

The problem whether "home instinct " occurs in European hare was not studied to date, although individual cases of return of an introduced hare to its place of origin were reported (K o e n e n, 1956; S z c zer- 
Table 1.

Detailed data concerning: hare's origin, introduction, and distance of returning.

\begin{tabular}{|c|c|c|c|c|}
\hline $\begin{array}{l}\text { Number and sex } \\
\text { of catching }\end{array}$ & $6062 / 58$, ๆ & $6008 / 58$, ᄋ & $6608 / 58, c^{\circ}$ & $6524 / 58, \quad$ ? \\
\hline $\begin{array}{l}\text { Date and place } \\
\text { of catching }\end{array}$ & \multicolumn{2}{|c|}{$\begin{array}{l}21 \text { to } 25 \text { January, } 1958 \\
\text { Czempiń, Poznań district }\end{array}$} & \multicolumn{2}{|c|}{$\begin{array}{l}11 \text { to } 14 \text { December, } 1958 \\
\text { Czempiń, Poznań district }\end{array}$} \\
\hline $\begin{array}{l}\text { Date, number of } \\
\text { released animals } \\
\text { and the place of } \\
\text { release }\end{array}$ & \multicolumn{2}{|c|}{$\begin{array}{c}23 \text { to } 27 \text { January, } 1958 \text {, } \\
500 \text { animals, } \\
\text { Manowo, Koszalin district }\end{array}$} & \multicolumn{2}{|c|}{$\begin{array}{l}13 \text { to } 16 \text { December, } 1958 \\
300 \text { animals, } \\
\text { Kosobudy, Lublin district }\end{array}$} \\
\hline $\begin{array}{l}\text { Date and place } \\
\text { of recapture }\end{array}$ & $\begin{array}{l}\text { Jan. } 13,1960, \\
\text { Czempiń }\end{array}$ & $\begin{array}{l}\text { July } 18,1962, \\
\text { Czempiń }\end{array}$ & $\begin{array}{l}\text { Feb. 17, 1960, } \\
\text { Czempiń }\end{array}$ & $\begin{array}{l}\text { Jan. 8, 1962, } \\
\text { Czempiń }\end{array}$ \\
\hline Distance in $\mathrm{km}$. & \multicolumn{2}{|c|}{229} & \multicolumn{2}{|c|}{464} \\
\hline Remarks & $\begin{array}{l}\text { Caught } 3 \mathrm{~km} \\
\text { from the crgi- } \\
\text { nal place of } \\
\text { capture }\end{array}$ & $\begin{array}{c}\text { Found dead at } \\
\text { the orginal } \\
\text { place of cap- } \\
\text { ture }\end{array}$ & $\begin{array}{c}\text { Caught } 2 \mathrm{~km} \\
\text { from the orgi- } \\
\text { nal place of } \\
\text { capture }\end{array}$ & $\begin{array}{l}\text { Found dead } 5 \\
\mathrm{~km} \text { from the } \\
\text { original place } \\
\text { of capture }\end{array}$ \\
\hline
\end{tabular}

biński, 1962 and others). The data given below may be useful to investigators interested in this problem. Moreover, these data indicate that returns occur in the European hare.

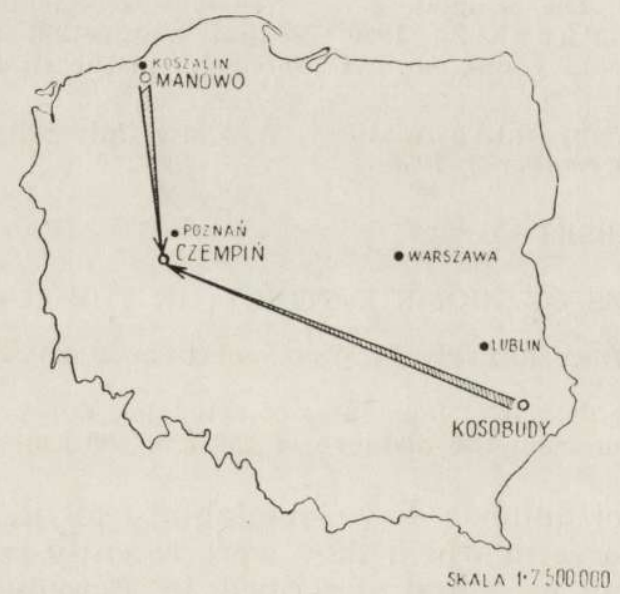

Fig. 1. Distribution of places of origin and introduction.

In January and in December 1958 hares were captured in the Experimental Breeding Centre of the Polish Hunting Union in Czempin (Poznan district) and introduced to areas with low density of hare population. Four hares, two of the January and two of the December catching, returned to the place they were caught. Detailed data are given in the table 1; fig. 1 gives the location of points of introduction and the distances traveled by hares returning to their place of origin. Considerable distance 
between the points of introduction and the Centre seems worth mentioning.

The described cases appear to represent the directional, migration to the point of destination and may indicate the existence of shome instinct" in the European hare.

\section{REFERENCES}

Fen juk B. K., 1941: »Instinkt doma" u gryzunov, Prir., 3: 51-58. Fenjuk B. K. \& P op ova A. A., 1940: Zametki o migracijah myševidnyh gryzunov pod vlijanijem »instynkta doma«, Vestn. mikrob. epid. i parazit., 19, 1: 104-120. J o h nS o n M. S., 1926: Activity and distribution of certain wild mice in relation to biotic communities, J. Mammal., 7, 4. K o en en F., 1956: Der Feldhase. A. Ziemsen Verlag, 1: 1-80. Wittenberg Lutherstadt. M uri e O. J. \& M uri e A., 1931: Travels of Peromyscus. J. Mammal., 12. S ch mid B., 1936: Ǔber die Heimkehrfärhigkeit von Waldmäusen (Mus silvaticus L.), Ztschr. vergl. Physiol., 23, 1. S z c zer biński W., 1962: Przyrodnicze podstawy łowiectwa, Łowiec pol., 2, 1173: $2-3$. Towns en d M. T., 1935: Studies on some of small mammals of central New York, Roosevelt Wild Life Ann., 4.

Institut of Ecology, Polish Academy of Sciences, Warszawa, Nowy Swiat 72. Fieceived, September 10, 1966.

\section{Bogusław BOBEK \& Andrzej BARTKE}

\section{A BANK VOLE CLETHRIONOMYS GLAREOLUS (S C H R E B E R, 1780) OF EXTREME NON-AGOUTI PHENOTYPE.}

NORNICA RUDA, CLETHRIONOMYS GLAREOLUS (S CHREBER, 1780)

O FENOTYPIE EXTREME NON-AGOUTI.

A melanistic specimen of the bank vole, Clethrionomys glareolus (S chreb.) was caught in the Niepolomicka Forest near Cracov. The animal was uniformly black; its coat colour corresponded to the phenotype of homozygous extreme non-agouti $(\mathrm{a} / \mathrm{a}$ ) laboratory mice.

A melanistic individual of the bank vole, Clethrionomys glareolus (Schreber, 1780) was caught in October 1966 while trapping small rodents on the edge of Niepołomicka Forest, near the village of Ispina $\left(50^{\circ} 07^{\prime} \mathrm{N}\right.$. lat. $-20^{\circ} 23^{\prime} \mathrm{E}$. long.). It was an adult male in autumn molting. The animal had the following body dimensions: weight $-18.2 \mathrm{~g}$, body length $-94 \mathrm{~mm}$, tail length $-41 \mathrm{~mm}$ and hind foot length $-17.5 \mathrm{~mm}$.

The bank vole has an agouti type coat colour similar to the majority of wild rodents. The bottom part of every hair is black and the upper part is lighter, namely dark red on the dorsum and dull yellow on the ventrum. All hair of the above described animal were black from the tip to the bottom and consequently the coat colour was solid deep black. The coat on the dorsum was slightly more glossy than on the ventrum, probably due to the larger number of guard hair and not to the differences in pigmentation. The coat colour of this specimen corresponded to No. 15 of the Ostwald (1923) colour scale. The skin of a melanistic bank vole is compared with the skin of a typically coloured bank vole in Fig. 1.

The coat colour of the described melanistic bank vole does not differ 